PACS:61.05.cp, 61.43.Dq, 61.72.Yx, 61.72.Mm, 61.82.Fk, 68.37.Hk, 68.55._a, 85.30.Tv

\title{
TUNING OF SnS THIN FILM CONDUCTIVITY ON ANNEALING IN AN OPEN AIR ENVIRONMENT FOR TRANSISTOR APPLICATION
}

\author{
(D) Thomas Daniel ${ }^{\mathrm{a}, \mathbf{b}_{*}}$, (D) Uno Uno ${ }^{\mathrm{b}}$, (D) Kasim Isah ${ }^{\mathrm{b}}$, (D) Umaru Ahmadub \\ ${ }^{a}$ Department of Physics/Geology/Geophysics, Alex Ekwueme-Federal University Ndufu-Alike \\ Ikwo, P.M.B 1010, Ebonyi state, Nigeria \\ ${ }^{b}$ Department of Physics, Federal University of Technology Minna \\ P.M.B 065, Minna, Niger state, Nigeria \\ *Corresponding Author: danielojonugwathomas@gmail.com \& daniel.thomas@funai.edu.ng \\ Received November 30, 2019; revised January 24, 2020; accepted March 12, 2020
}

The study aimed at enhancement and optimisation of SnS conductivity via annealing for field effect transistor's semiconductor channel layer application. Interstitials and vacancies in SnS films are known to cause carrier traps which limit charge carriers and hence limit the achievement of the threshold voltage for a field effect transistor operation. Tuning of SnS conductivity for transistor application is of emerging interest for novel device operation. SnS thin film semiconductors of $0.4 \mu m$ thickness were deposited using Aerosol assisted chemical vapour deposition and annealed in open air at annealing temperatures of 150, 200, 250, 300 and $350^{\circ} \mathrm{C}$. Variation of the annealing temperature from 150 through $250^{\circ} \mathrm{C}$ enhances the crystallinity of the annealed thin film samples by increasing the number of crystallites of the annealed films which is also buttress by the decreasing values of FWHM. However a further decrease in crystallite size at higher annealing temperature of 300 to $350{ }^{\circ} \mathrm{C}$ was observed which could be attributed to the fragmentation of clusters of crystallites at higher annealing temperature. Increase in annealing temperature increases grain size leading to the reduction in grain boundaries and potential barrier thereby changing the structure and phase of the films which in essence affects the electrical conductivity of the SnS thin films. The films annealed at $250{ }^{\circ} \mathrm{C}$ exhibited optimum conductivity. The average hall coefficients of the samples deposited at 150 to $250^{\circ} \mathrm{C}$ were positive which indicates that the films annealed at this temperature range are of $\mathrm{p}$ type conduction while the average hall coefficients of the samples deposited at 300 and $350{ }^{\circ} \mathrm{C}$ were negative indicating that the films are of $\mathrm{n}$ type conduction. The conductivity change is essential for the use of SnS as a semiconductor channel layer especially in a field effect transistor where the device can be tuned to work as a p type or $n$ type semiconductor channel layer.

KEY WORDS: SnS thin film, annealing, conductivity, grain size, transistor, semiconductor

Metal chalcogenides such as Tin(II) sulphide (SnS) and metal dichalcogenides such as Tin(IV) sulphide $\left(\mathrm{SnS}_{2}\right)$ are of interest as potential candidates for the semiconductor transport channel of field effect transistor and has been previously used in an electric double layer field effect transistor [1]. Chalcogenides consist of a transition element and one or more chalcogenides elements. SnS thin film is abundance in the earth's crust with an orthorhombic crystal structure. It has been reported to be of $\mathrm{p}$ type conductivity with a carrier concentration on the order of $10^{16} \mathrm{~cm}^{-3}$ and hole mobility of $1.4 \mathrm{~cm}^{2} \mathrm{~V}^{-1} \mathrm{~s}^{-1}[2]$.

The operation of a field effect transistor is essentially dependent on the choice of semiconductor channel layer material since the voltage required in switching a transistor and also the minimum gate to source voltage differential that is needed to create a charge carrier conducting path between the source and drain is dependent on the transistor semiconductor channel layer [3].

However, oxides, nitrides, carbon nanotubes and organic semiconductor have been the widely reported materials [4]. Therefore, the investigation of other semiconductor materials such as $\mathrm{SnS}$ thin film is of interests for novel field effect transistor performances. An essential factor to be considered in the investigation of $\mathrm{SnS}$ as a semiconductor material for transistor application is the conductivity and conductivity type since a field transistor can operate as p-type or n-type carrier channel. Optimisation of conductivity is essential for attainment of transistor threshold voltage, easy reproducibility of film properties and simplicity in device design.

The electrical conductivity of semiconductor thin films strongly depends on the preparation conditions and techniques. Low resistive films are often obtained by the creation of excess metal atoms through heat treatment called annealing to fill up interstitials and vacancies which are structural defects in an SnS thin film or by the incorporation of suitable and control amount of dopants [5].

Annealing is the method of conductivity tuning or control employ in this research which is dependent on the choice of annealing temperature and annealing environment. For the choice of annealing temperature, it is generally recommended that the annealing temperature of any material should be less than one-third of its melting point [5]. Since the melting point of $\mathrm{SnS}$ is approximately $900{ }^{\circ} \mathrm{C}$, the annealing temperature for $\mathrm{SnS}$ should be $\leq 300{ }^{\circ} \mathrm{C}$. As such the annealing was carried out at a choice temperature range of 150 to $350^{\circ} \mathrm{C}\left(150,200,250,300\right.$ and $\left.350{ }^{\circ} \mathrm{C}\right)$. A starting annealing temperature of 150 was chosen to allow for minimum temperature required for reacting components. Open air annealing in atmosphere oxygen was chosen due to its cost effectiveness in set up and acquisition which could scale down the deposition cost.

Hence, we report for the first time the tuning of $\mathrm{SnS}$ carrier conductivity and conductivity type with variation of annealing temperature in an open air environment for field effect transistor application. 


\section{EXPERIMENTAL PROCEDURE}

Soda lime glass substrates were cleaned using the cleaning methods described as follows: (a). The substrates were washed in sodium lauryl sulphate (SLS) solution to remove oil and protein. (b). To remove the organic contaminants, the substrates were immersed in piranha solution $\left(\mathrm{H}_{2} \mathrm{SO}_{4}: \mathrm{H}_{2} \mathrm{O}_{2}(3: 1)\right)$ for 30 minutes. (c). The substrates were then ultrasonically cleaned in distilled water using a sonicator and kept in methanol until it is ready to be used. (d). Finally, to use the substrate for deposition process, the substrate were taken from the methanol and dried in air at $150{ }^{\circ} \mathrm{C}$. Six samples of as deposited SnS semiconductor thin films were deposited individually using $0.1 \mathrm{M}$ Tin chloride dehydrates and $0.2 \mathrm{M}$ of Thiourea which was weighed in stoichiometric proportion and dissolve in ethanol solvent $(0.2 \mathrm{M}$ of Thiourea $\left(\mathrm{CH}_{4} \mathrm{~N}_{2} \mathrm{~S}\right)$ solution was prepared with $0.60896 \mathrm{~g}$ of $\mathrm{CH}_{4} \mathrm{~N}_{2} \mathrm{~S}$ salt made up to $10 \mathrm{ml}$ of ethanol as solvent while $0.1 \mathrm{M} \mathrm{SnCl}_{2} .2 \mathrm{H}_{2}$ Osolution was prepared with $0.90252 \mathrm{~g}$ of $\mathrm{SnCl}_{2} .2 \mathrm{H}_{2} \mathrm{O}$ salt made up to $10 \mathrm{ml}$ of ethanol as solvent). The two solutions were mixed and stirred for 1 hour using a magnetic stirrer at room temperature, after which the resulting solution was then deposited on the substrate by aerosol assisted chemical vapour deposition (AACVD) at a constant substrate temperature of $258^{\circ} \mathrm{C}$. Five out of the six as-deposited samples of SnS thin film were annealed in open air at annealing temperatures of $150,200,250,300$ and $350^{\circ} \mathrm{C}$ while one of the samples was left unannealed. The as deposited and the annealed samples were allowed to cool to room temperature before undergoing film characterisation.

The crystal phase analysis was carried out at room temperature using X-ray diffractrometry (D8 Advance, Bruker AXS, 40Kv, $40 \mathrm{~mA})$ with monochromatic $\mathrm{CuK} \alpha(\lambda=1.540598 \AA)$ over a scan mode of step size $0.034^{\circ}$ and counts accumulated for $192.1 \mathrm{~s}$ at each step for $2 \theta$ ranging from $20^{\circ}$ to $80^{\circ}$.The XRD diffractogram was obtained using OriginPro 2018 software with the FWHM for the peaks estimated using a Gaussian function. Results were analysed with the scientific graphing analysis software and phase identification was done using the inorganic crystal structure data (ICSD) pattern [6] after which the crystallite size, d-spacing, lattice parameter, dislocation density and micro strain were analysed respectively.

The lattice parameters $a, b$ and $c$ value for the orthorhombic crystallographic system of SnS thin film was calculated from the observed values of $2 \theta$ using d values (interplaner spacing) for the orthorhombic structure [7]

$$
1 / d^{2} h k l=h^{2} / a^{2}+k^{2} / b^{2} l^{2} / c^{2}
$$

XRD pattern of the films were first indexed after which three peaks whose (hkl) is known were selected and resolved for $\mathrm{a}, \mathrm{b}$ and $\mathrm{c}$ lattice constants of the $\mathrm{SnS}$ thin film which is also equivalent to:

$$
a=\frac{1}{d_{101}}=\frac{b c \sin \alpha}{V} ; b=\frac{1}{d_{040}}=\frac{a c \sin \beta}{V} ; c=\frac{1}{d_{002}}=\frac{a b \sin \gamma}{V} .
$$

Where $\mathrm{V}$ (unit cell volume)=abc (for orthorhombic), $\mathrm{d}$ is the space between lattice planes, $\mathrm{h} \mathrm{k} 1$ are the miller indices while $\alpha, \beta, \gamma$ are the diffraction angles. Where $\mathrm{d}$ is the space between lattice planes and $\mathrm{h} \mathrm{k} l$ are the miller indices. The atomic spacing parameter $d$ was estimated from the Bragg's equation [8]:

$$
\begin{gathered}
2 d \sin \theta=n \lambda \\
d=\frac{\lambda}{2 \sin \theta}
\end{gathered}
$$

where $\mathrm{n}=1, \lambda=1.5406 \mathrm{~A}^{0}$. The average crystallite size of the films were calculated using the equation:

$$
\mathrm{D}=\frac{0.9 \lambda}{\beta \cos \theta}
$$

$\beta=$ full width at half maximum (FWHM), $\theta=$ diffraction angle, $\mathrm{k}=$ Shape factor and $\lambda=$ wavelength of the X-rays $(1.5406 \AA)$ and $\mathrm{D}=$ average crystallite size respectively.

Dislocation density $\delta$ was calculated using D [7]:

$$
\delta=\frac{1}{D^{2}}
$$

$\mathrm{D}$ is the grain size of the film. The micro-strain $\varepsilon$ was estimated using the equation [8],

$$
\varepsilon=\frac{\beta}{4 \tan \theta}
$$

Quantitative information about the preferential crystallite orientation of the SnS thin films were obtained from the texture coefficient (TC) using the relation [6]:

$$
\mathrm{TC}=\frac{I / I_{O}}{\left(1 /{ }_{N}\right) \Sigma_{N}\left(I_{I_{O}}\right)}
$$

I is the measured intensity of the intense peak in the XRD spectrum, $I_{0}$ is the intensity for completely random sample or the standard intensity of the hkl plane taken from the JCPDS 00-039-0354 card and $\mathrm{N}$ is the number of reflections considered in the analysis.

The morphology and the microstructure of the $\mathrm{SnS}$ thin film was characterized using High Resolution Scanning Electron Microscopy (HR-SEM, Zeiss) while the elemental composition of the as deposited and the annealed films were characterised by an Energy dispersive X-ray spectroscopy (EDS; Oxford instrument) attached to the SEM. The instrument was operated at a voltage of $20 \mathrm{kV}$ while the images were captured at $5 \mathrm{kV}$. A Profilometer (VEECO 
DEKTAK 150) was used to carry out measurement of the thickness of the as deposited and the annealed SnS thin films. After which the carrier density, carrier mobility and carrier type were determined by an ECOPIA Hall Effect measurement system (HMS 3000 Hall measurement system) based on Van der pauw configuration. The current was varied from $\pm 1 \mathrm{~mA}$ to $1 \mathrm{~mA}$ at room temperature. A magnetic field of 8000 gauss was employed for the Hall Effect measurement.

\section{RESULTS AND DISCUSSION}

Thickness measurement and compositional analysis of the annealed SnS thin films

The thickness of the as deposited and the annealed films were found to be $0.4 \mu \mathrm{m}$. The main constituents' elements and their relative concentrations are given in Table 1.The $\mathrm{SnS}$ thin film annealed at the different annealing temperatures were smooth, pin hole free and adheres firmly to the soda lime glass substrate surface. The films were all brown in colour without any significant colour change. The composition of the SnS thin films varied with the increase in annealing temperature as shown in Table 1.

SnS thin film elemental composition (atomic percent) at varied annealing Temperatures.

Table 1

\begin{tabular}{|c|c|c|c|c|c|c|c|c|}
\hline $\mathrm{T}_{\mathrm{A}}\left({ }^{\circ} \mathrm{C}\right)$ & $\begin{array}{c}\mathrm{Sn} \\
\text { (at. \%) }\end{array}$ & $\begin{array}{c}\mathrm{S} \\
\text { (at. \%) }\end{array}$ & $\begin{array}{c}\mathrm{Ca} \\
\text { (at. \%) }\end{array}$ & $\begin{array}{c}\mathrm{Na} \\
\text { (at. \%) }\end{array}$ & $\begin{array}{c}\mathrm{Cl} \\
\text { (at. \%) }\end{array}$ & $\begin{array}{c}\mathrm{Si} \\
\text { (at. \%) }\end{array}$ & $\begin{array}{c}\mathrm{O} \\
\text { (at. \%) }\end{array}$ & $\begin{array}{c}\text { TOTAL } \\
100\end{array}$ \\
\hline 0 & 29.851 & 52.154 & 8.352 & 1.044 & 5.620 & 1.740 & 1.250 & 100 \\
\hline 150 & 29.804 & 52.203 & 8.345 & 1.040 & 5.624 & 1.743 & 1.249 & 100 \\
\hline 200 & 29.873 & 52.131 & 8.350 & 1.041 & 5.622 & 1.744 & 1.248 & 100 \\
\hline 250 & 30.572 & 51.432 & 8.346 & 1.042 & 5.623 & 1.742 & 1.248 & 100 \\
\hline 300 & 29.634 & 52.374 & 8.349 & 1.044 & 5.621 & 1.741 & 1.247 & 100 \\
\hline 350 & 29.770 & 52.233 & 8.347 & 1.043 & 5.622 & 1.743 & 1.251 & 100 \\
\hline
\end{tabular}

Figure 1 gives the EDX spectrum of the as deposited SnS thin film and the SnS samples annealed at annealing temperatures of $150,200,250,300$ and $350^{\circ} \mathrm{C}$. From the figures, it is evident that the film contained Tin (Sn) and Sulpur (S) elements which are as labelled. However minute quantity of $\mathrm{Na}, \mathrm{Ca}, \mathrm{Si}, \mathrm{Cl}$ and $\mathrm{Ca}$ were also observed which could be attributed to their presence in the glass substrates. The decrease in sulphur content at 150 to $250{ }^{\circ} \mathrm{C}$ could be attributed to the rate of re-evaporation of sulphur from the $\mathrm{SnS}$ film layers with increase in annealing temperature due to the high vapour pressure of Sulpur or the loss of Sulpur during annealing at higher temperatures $[5,9]$.

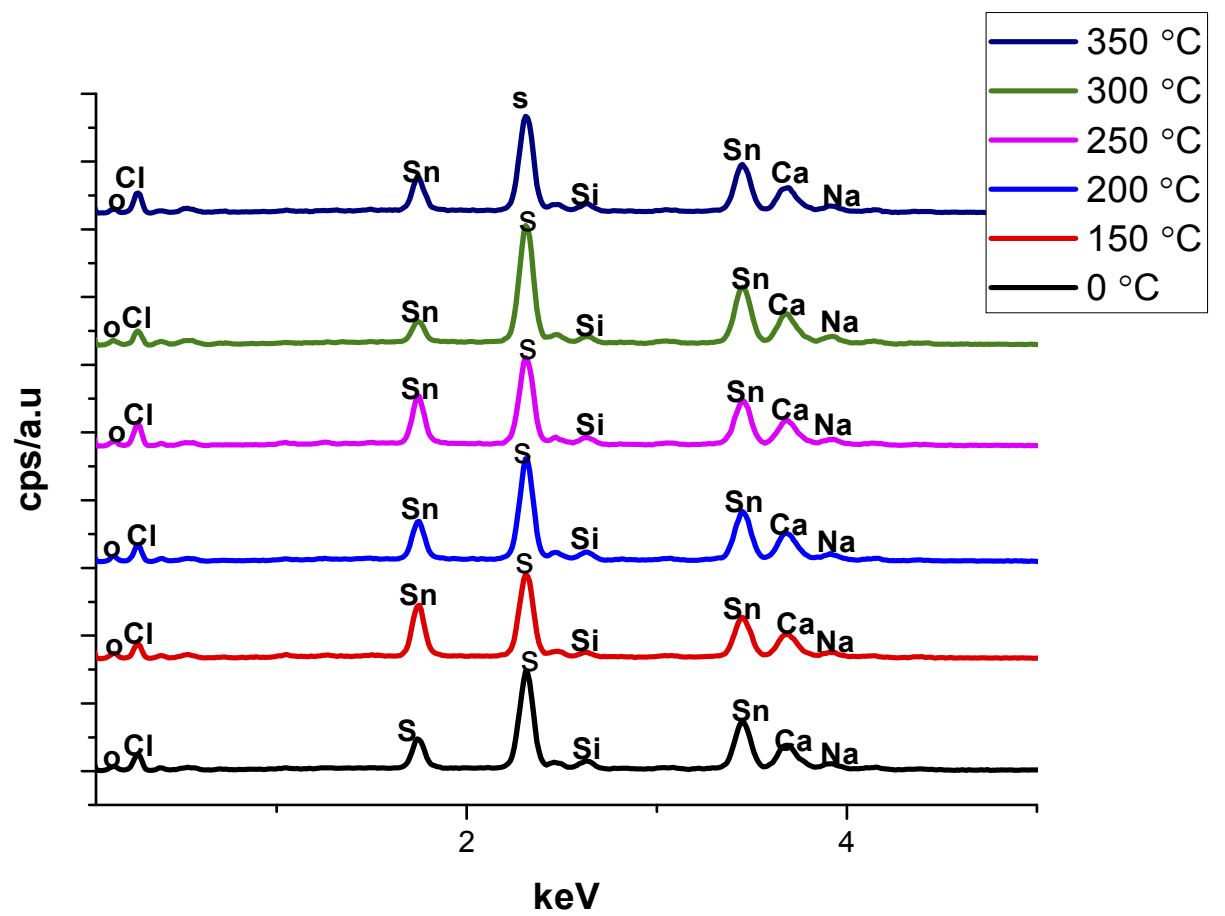

Figure 1. EDS spectrum of the $\mathrm{SnS}$ thin film semiconductor annealed at $0,150,200,250,300$ and $350^{\circ} \mathrm{C}$.

\section{X-ray diffractomer (XRD) Analysis}

Figure 2. Show the XRD pattern of $\mathrm{SnS}$ thin film annealed at different annealing temperatures. The peaks were identified using the JCPDS card number 39-0354 data and are labelled with corresponding orientations. All reflections were indexed to orthorhombic SnS phase as compared with the standard JCPDS card. The X-ray diffractogram or 
spectrum of the annealed films exhibited peaks of different orientations at $2 \Theta$ values of approximately $31.7^{\circ}$ and $66.8^{\circ}$ corresponding to (040) and (080) peaks for samples annealed at 0 (as deposited), 150, 200, 300 and $350{ }^{\circ} \mathrm{C}$ annealing temperature. The position of the $(040)$ peak shifted with annealing to higher $2 \Theta$ values from initial value of $31.71^{\circ}$ for as deposited to a maximum value of $31.74^{\circ} \mathrm{C}$ for the annealed films which could be due to the release of intrinsic strain through annealing.

No impurities peaks of elemental sulphur, tin or other tin sulphide phases were identified in the XRD pattern of the annealed films which buttress the formation of pure $\mathrm{SnS}$ phase and absence of oxidation of $\mathrm{SnS}$ with annealing in open air. The as deposited film possess a broad peak being characteristics for an amorphous material or one with very small nano-crystals. The annealed $\mathrm{SnS}$ films exhibited an orthorhombic structure with calculated lattice parameters of $\mathrm{a}=0.429 \mathrm{~nm}, \mathrm{~b}=1.123 \mathrm{~nm}$ and $\mathrm{c}=0.399 \mathrm{~nm}$ with no change in the structure of $\mathrm{SnS}$ films with changes in annealing temperature. The observed d spacing as compared to the standard d spacing is shown in table 2.

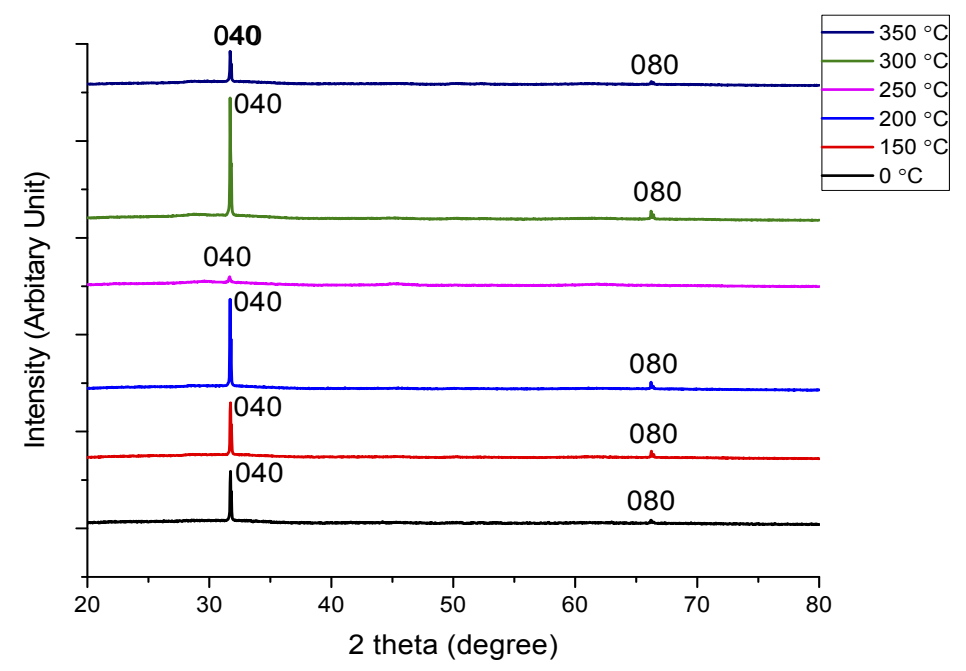

Figure 2. XRD pattern for $\mathrm{SnS}$ thin film at annealing temperatures of $150,200,250,300$ and $350^{\circ} \mathrm{C}$.

Observed and standard d spacing for annealed SnS thin films

Table 2.

\begin{tabular}{|c|c|c|c|c|}
\hline $\mathrm{S} / \mathrm{N}$ & $\begin{array}{c}\text { Annealing } \\
\text { Temperature }\left({ }^{\circ} \mathrm{C}\right)\end{array}$ & $2 \Theta\left(^{\circ}\right)$ & $\begin{array}{c}\text { Observed } \\
\mathrm{D} \text { spacing }(\dot{\boldsymbol{A}})\end{array}$ & $\begin{array}{c}\text { Standard } \\
\mathrm{D} \text { spacing }(\dot{\boldsymbol{A}})\end{array}$ \\
\hline 1 & 0 & 31.73912 & 2.8201 & 2.8000 \\
\hline 2 & 150 & 31.74278 & 2.8167 & 2.8000 \\
\hline 3 & 200 & 31.7253 & 2.8182 & 2.8000 \\
\hline 4 & 250 & 31.71153 & 2.8194 & 2.8000 \\
\hline 5 & 300 & 31.72585 & 2.8181 & 2.8000 \\
\hline 6 & 350 & 31.72785 & 2.8180 & 2.8000 \\
\hline
\end{tabular}

The calculated d spacing are closely related to the standard JCPDS data. Although a slight difference occurs in the values which could be attributed to the presence of unit cell volume contraction that might signify the presence of strain in the annealed films [5]. The calculated texture coefficient values of the five annealed samples is given in Table 3.

Table 3.

Calculated texture coefficient for the annealed SnS thin films

\begin{tabular}{|c|c|c|c|}
\hline $\mathrm{S} / \mathrm{N}$ & $\begin{array}{c}|c| \\
\text { Tempealing }\end{array}$ & \multicolumn{2}{c|}{ Texture coefficient (TC) } \\
& TC (040) & 0.10 \\
\hline 1 & 150 & 1.09 & 0.83 \\
\hline 2 & 200 & 1.17 & 0.95 \\
\hline 3 & 250 & 2.52 & 0.60 \\
\hline 4 & 300 & 1.05 & ${ }^{\circ} \mathrm{C}$ \\
\hline
\end{tabular}

The value obtained shows that all the TC values of (040) plane of the annealed SnS thin film component are larger than 1 which indicates that all the $\mathrm{SnS}$ films are polycrystalline with preferred orientation along the (040) plane and denotes that the number of grains along the (040) plane is more than that on the other planes $[9,10]$. The degree of 
preferential orientation initially increased with increase in annealing temperature for samples annealed at 150 to $250{ }^{\circ} \mathrm{C}$ with a maximum value at the sample annealed at $250^{\circ} \mathrm{C}$ for each plane after which it decreases.

At annealing temperature of $150^{\circ} \mathrm{C}$, it could be inferred that the $\mathrm{SnS}$ thin film undergoes incomplete recrystallization giving rise to a peak with similar intensity to that of the as deposited film. The orientation and intensity of the film increases with increase in annealing temperature to $200{ }^{\circ} \mathrm{C}$ which could be attributed to improvement in crystallinity and signifies decrease in dislocation density and density of grain boundaries as a result of decrease of donor sites that are trapped at the dislocation and grain boundaries. However with increase in annealing temperature to $250^{\circ} \mathrm{C}$, the intensity of SnS thin film of (040) preferencial orientation decreases which could be attributed to the decomposition and re-evaporation of adsorption atoms away from the surface as the $\mathrm{SnS}$ becomes thermodynamically unstable at high annealing temperatures which leads to increase in the speed of atoms so as to look for a site of lowest surface energy structure leading to a formation of a more improved crystalline film. A further increase in the intensity and crystallinity of the SnS films occurred at annealing temperature of $300-350{ }^{\circ} \mathrm{C}$ which could be attributed to the increase in thermal oscillation of atoms in their lattice position at high temperatures.

The peak associated with the (040) plane was used to calculate the structural parameters of the films been the preferred orientation of the annealed $\mathrm{SnS}$ thin films. The summarised structural parameters are given in in table 4 while figure 3 shows the variation of average crystallite size with annealing temperatures of $150,200,250,300$ and $350^{\circ} \mathrm{C}$.

Table 4.

Summary of calculated structural parameters for the annealed SnS thin films

\begin{tabular}{|l|l|l|l|l|l|l|}
\hline & $\begin{array}{l}\text { Annealing } \\
\text { Temperature }\left({ }^{\circ} \mathrm{C}\right)\end{array}$ & $\begin{array}{l}\text { Full width } \\
\text { half maximum } \\
\boldsymbol{\beta}\left({ }^{\circ}\right)\end{array}$ & $2 \Theta\left({ }^{\circ}\right)$ & $\begin{array}{l}\text { Average } \\
\text { crystallite size } \\
\mathrm{D}(\mathrm{nm})\end{array}$ & $\begin{array}{l}\text { Dislocation } \\
\text { density } \boldsymbol{\delta} \times \\
\mathbf{1 0}^{\mathbf{1 4}}\left(\text { Lines } / \mathbf{m}^{\mathbf{2}}\right)\end{array}$ & $\begin{array}{l}\text { Micro strain} \boldsymbol{\varepsilon} \\
\times \mathbf{1 0}^{-\mathbf{4}}\end{array}$ \\
\hline & 0 (as deposited) & 0.13633 & 31.73912 & 60.57 & 2.73 & 5.72 \\
\hline & 150 & 0.14008 & 31.74278 & 58.95 & 2.88 & 5.88 \\
\hline & 200 & 0.13139 & 31.72530 & 62.94 & 2.52 & 5.52 \\
\hline & 250 & 0.12644 & 31.71153 & 65.30 & 2.35 & 5.31 \\
\hline & 300 & 0.13343 & 31.72585 & 61.89 & 2.61 & 5.60 \\
\hline & 350 & 0.15962 & 31.72785 & 51.73 & 3.74 & 6.70 \\
\hline
\end{tabular}

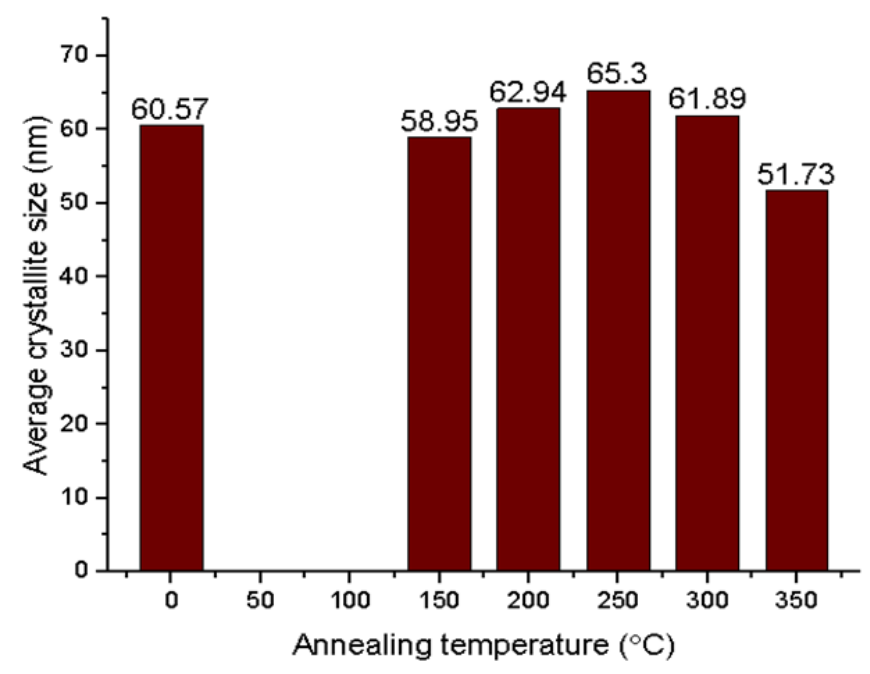

Figure 3. Composite variation of average crystallite size with annealing temperatures

Figure 3 shows the variation of average crystalline size evaluated. The crystallite size initial decreased to $58.95 \mathrm{~nm}$ from the value of $60.57 \mathrm{~nm}$ of the as deposited $\mathrm{SnS}$ thin film at $150^{\circ} \mathrm{C}$ annealing temperature which could be as a result of the insufficient temperature to move grain boundaries or the fragmentation of clusters of SnS crystals to initiate recrystallization [5]. The crystallite size however increases with increase in annealing temperature from $58.95 \mathrm{~nm}$ for SnS film annealed at $150^{\circ} \mathrm{C}$ to $62.94 \mathrm{~nm}$ for the film annealed at $200^{\circ} \mathrm{C}$ and to $62.94 \mathrm{~nm}$ for the film annealed at $250^{\circ} \mathrm{C}$. Increasing the annealing temperature from 150 through $250^{\circ} \mathrm{C}$ enhances the crystallinity of the annealed thin film samples by increasing the number of crystallites of the annealed films which is also buttress by the decreasing values of FWHM and correlates with the report of [11]. Annealing enables Oswald ripening which is the consolidation and growth of larger grains at the expense of smaller ones with a rate of occurrence aided by temperature. The increase in crystallite size could also be attributed to the decrease in grain boundary and reduction in deformation as well as defects in the crystals which signifies increase of degree of perfection of grains with the removal of defects and the reduction of pores. 
However a further decrease in crystallite size at higher annealing temperature of 300 to $350{ }^{\circ} \mathrm{C}$ was observed which could be attributed to the fragmentation of clusters of crystallites at higher annealing temperature. The sample annealed at $250{ }^{\circ} \mathrm{C}$ exhibits the best crystallinity with the largest grain size and decrease in defects density and decrease in donor sites trapped at the dislocation and grain boundaries.

Micro strain $\varepsilon$ and dislocation density $\delta$ which are crystal defect parameters exhibits a reducing trend for the samples annealed at 150 to $250^{\circ} \mathrm{C}$ with increase in annealing temperature and with increase in average crystallite size. The decrease of dislocation density for $\mathrm{SnS}$ thin films annealed at 150 to $250^{\circ} \mathrm{C}$ indicates the presence of higher crystallinity of $\mathrm{SnS}$ films than the samples annealed at 300 to $350^{\circ} \mathrm{C}$ where the dislocation density and micro strain increases further.The change in the strain may be due to the recrystallization process in the SnS films. Also micro strain is an inherent and natural component of nano grained materials due to the large number of grain boundaries and the short spacing between them. Increase in crystal size with annealing temperature causes increase in surface energy which causes the varying magnitude of the strain [12].

\section{SEM Analysis}

The scanning electron microscopy micrograph at magnification of $20000 \mathrm{x}$ for all the annealed samples of $\mathrm{SnS}$ thin film at various annealing temperature as compared to the as deposited is shown in Fig. 4.

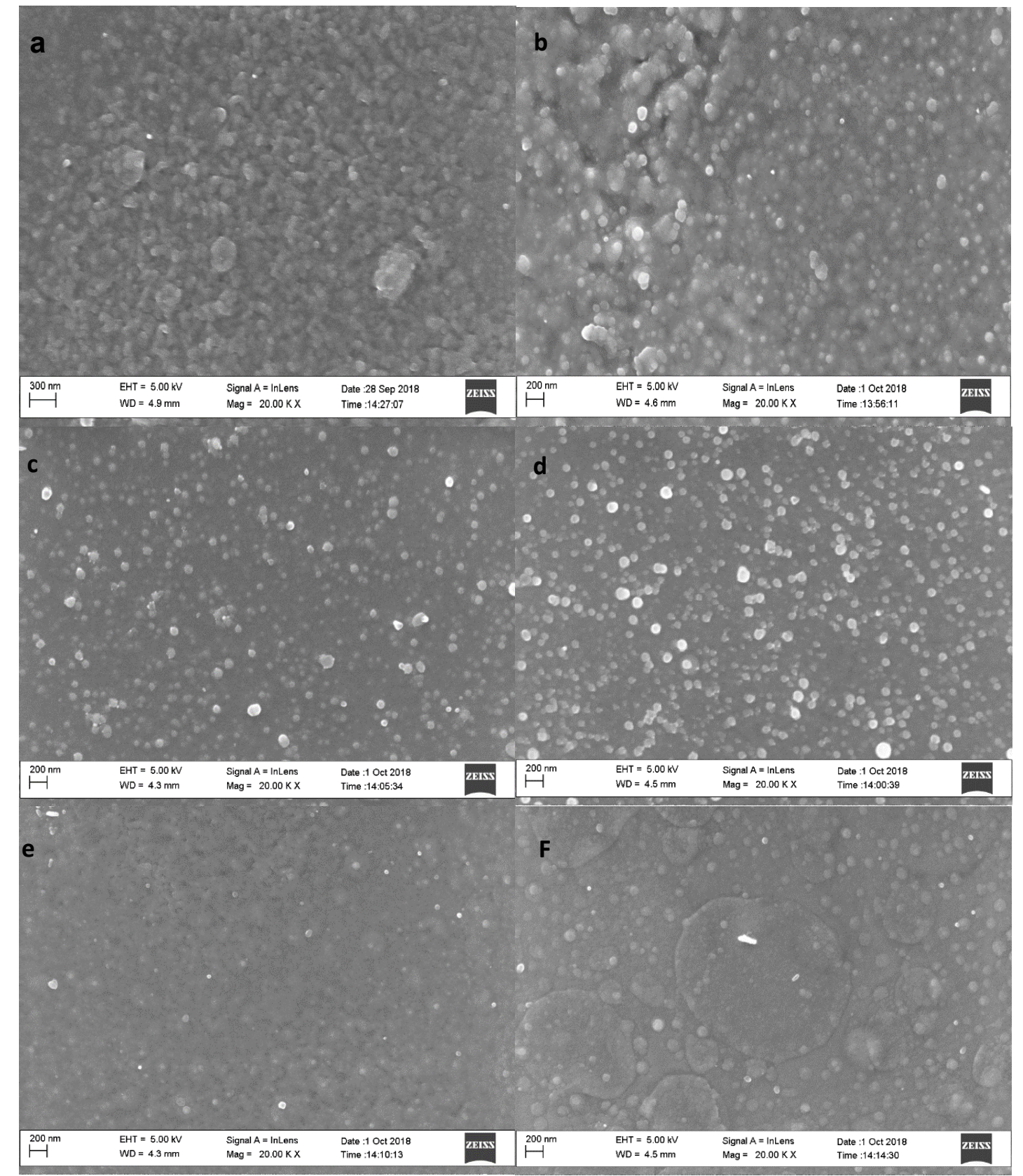

Figure 4. The surface morphology of SnS thin films annealed at $0,150,200,250,300$ and $350^{\circ} \mathrm{C}$. 
A gradual change was observed from the micrograph in the growth of grains of SnS films from island nature to a more densely packed thin film nature as the annealing temperature increases from 150 to $350{ }^{\circ} \mathrm{C}$. The grains lie randomly oriented with a decrease in grain boundaries with increase in annealing temperature. Similar results have been reported by [5]. Figure 5 shows that the grain size which is as labelled on each column increases with increase in annealing temperature.

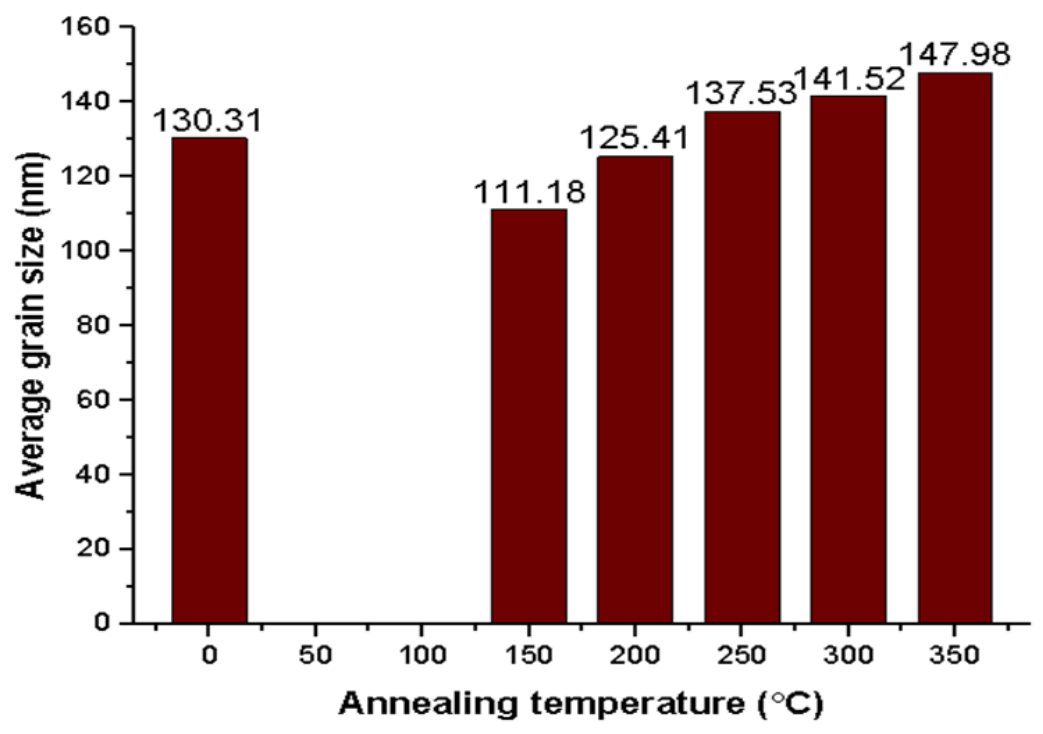

Figure 5. Composite average grain size plot for annealing temperatures of 150 to $350^{\circ} \mathrm{C}$.

Increasing the annealing temperature increases grain size leading to the reduction in grain boundaries and potential barrier which enhances the release of trap carriers thereby increasing the conductivity of the $\mathrm{SnS}$ thin film with annealing.

\section{Hall Effect measurement}

The Hall Effect measurement showing carrier concentration, average hall coefficient, carrier mobility, resistivity, conductivity and sheet resistance is shown in table 5 .

Table 5 .

Electrical parameters for annealed $\mathrm{SnS}$ thin films using Hall Effect measurement

\begin{tabular}{|l|l|l|l|l|l|}
\hline $\begin{array}{l}\text { Annealing } \\
\text { Temperature }\left({ }^{\circ} \mathrm{C}\right)\end{array}$ & $\begin{array}{l}\text { Bulk concentration } \\
\mathrm{N}_{\mathrm{b}}\left(\mathrm{cm}^{-3}\right)\end{array}$ & $\begin{array}{l}\text { Average Hall } \\
\text { coefficient } \mathrm{R}_{\mathrm{H}} \\
\left(\mathrm{cm}^{3} / \mathrm{c}\right)\end{array}$ & $\begin{array}{l}\text { Carrier mobility } \\
\mu\left(\mathrm{cm}^{2} / \mathrm{Vs}\right)\end{array}$ & $\begin{array}{l}\text { Resistivity } \boldsymbol{\rho} \\
(\Omega \mathrm{cm})\end{array}$ & $\begin{array}{l}\text { Conductivity } \boldsymbol{\sigma} \\
(\Omega \mathrm{cm})^{-1}\end{array}$ \\
\hline 0 & $2.238 \times 10^{10}$ & $6.928 \times 10^{9}$ & $4.337 \times 10^{3}$ & $3.612 \times 10^{5}$ & $2.768 \times 10^{-6}$ \\
\hline 150 & $2.850 \times 10^{10}$ & $1.795 \times 10^{10}$ & $1.523 \times 10^{5}$ & $1.217 \times 10^{4}$ & $8.214 \times 10^{-5}$ \\
\hline 200 & $3.010 \times 10^{10}$ & $1.833 \times 10^{10}$ & $1.571 \times 10^{5}$ & $1.121 \times 10^{4}$ & $8.921 \times 10^{-5}$ \\
\hline 250 & $3.167 \times 10^{10}$ & $1.971 \times 10^{10}$ & $1.619 \times 10^{5}$ & $1.025 \times 10^{4}$ & $9.756 \times 10^{-5}$ \\
\hline 300 & $-3.721 \times 10^{9}$ & $-8.678 \times 10^{9}$ & $1.692 \times 10^{4}$ & $1.249 \times 10^{5}$ & $8.008 \times 10^{-6}$ \\
\hline 350 & $-6.664 \times 10^{9}$ & $-9.367 \times 10^{9}$ & $3.905 \times 10^{4}$ & $1.241 \times 10^{5}$ & $8.057 \times 10^{-6}$ \\
\hline
\end{tabular}

Compared to the as deposited $\mathrm{SnS}$ thin film annealed at $0{ }^{\circ} \mathrm{C}$, the annealed samples showed improvement in their semiconducting properties. The average hall coefficients of the samples deposited at 150 to $250{ }^{\circ} \mathrm{C}$ are positive which indicates that the films annealed at this temperature range are of $\mathrm{p}$ type (with holes as majority carriers) conduction while the average hall coefficients of the samples deposited at 300 and $350{ }^{\circ} \mathrm{C}$ are negative indicating that the films are of n-type conduction. The change in conductivity could be attributed to the release of tin atoms with annealing at higher temperature. The inversion (transmutation) in type of carrier charge could also be related to impact defect due to crystal growth in material with changes in annealing temperature or the thermal oscillation of atoms in their lattice position at high temperature which may cause a release of atom from its location to filled space left behind. Annealing enhances increase carrier concentration, reduction in resistivity due to improvement in crystallisation and increase in grain size leading to decrease in defects density and crystal boundary which enhances increase in the SnS thin film conductivity.

With the increase of annealing temperature, the carrier concentration and mobility increases while the film resistivity decreases except that of films annealed at 300 and $350{ }^{\circ} \mathrm{C}$. The carrier concentration and mobility reached a maximum of $3.167 \times 10^{10} \mathrm{~N}_{\mathrm{b}}\left(\mathrm{cm}^{-3}\right)$ and $1.619 \times 10^{5}\left(\mathrm{~cm}^{2} / \mathrm{Vs}\right)$ with a p type conductivity. This could be explained by the fact that increase of annealing temperature leads to improved crystallisation and increase in grain size in the films which could enhance the decrease of crystal defects, grain boundary and crystal bonding reduction, hence the release of the 
electrons that are trapped at the grain boundary thereby decreasing resistivity and increasing conductivity. However above $250^{\circ} \mathrm{C}$, higher temperatures enhance stronger crystal lattice vibration which could results in crystal lattice defects. Such defects become dispersion centres leading to increase of films resistivity. Similar reports have been reported by [13].

\section{Temperature dependence of electrical conductivity}

A deposited film of $0.40 \mu \mathrm{m}$ thickness which was annealed at $250{ }^{\circ} \mathrm{C}$ was used to study the temperature dependence of electrical conductivity of the deposited $\mathrm{SnS}$ thin film by heating to a temperature of $300{ }^{\circ} \mathrm{C}$ after which the resistivity/conductivity was measured as the temperature reduced by $5{ }^{\circ} \mathrm{C}$ intervals. The obtained data was analysed using Arrhenius equation [14]. A plot of $\ln \left(\sigma / \sigma_{0}\right)$ versus $(1 / T)$ is given in Figure 7.

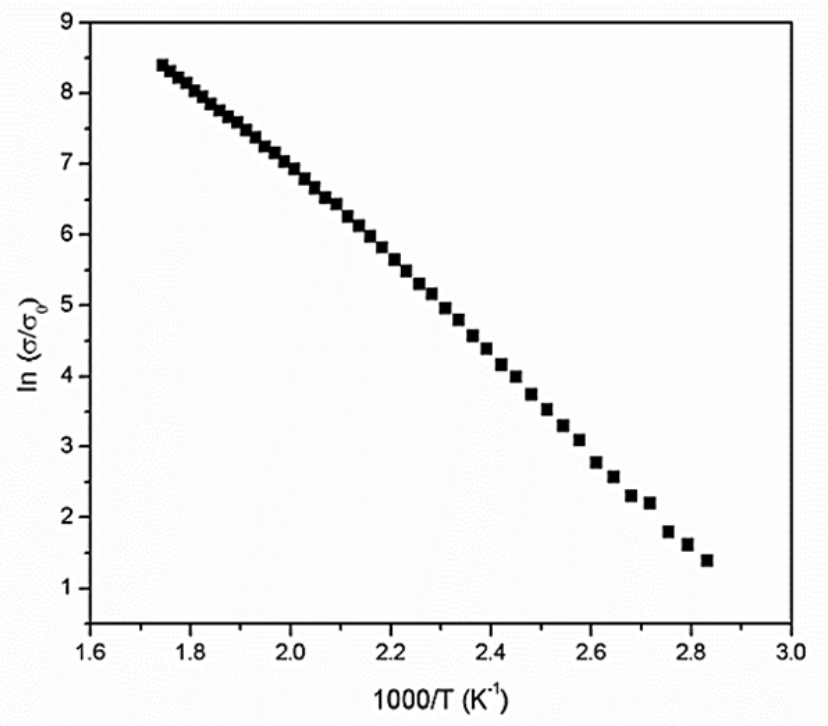

Fig. 7. The dependence of $\ln \left(\sigma / \sigma_{0}\right)$ versus $(1000 / \mathrm{T})$ for $\mathrm{SnS}$ thin film

The activation energy of the charge carriers evaluated from the slope of the curve was obtained as $0.520 \mathrm{eV}$. The value of the activation energy may be attributed to the deep acceptor states arising from the Sn vacancy which plays significant role in the p type carrier conductivity of the $\mathrm{SnS}$ semiconductor. The excess of non-metallic atoms (Sulpur) which is also evident in the elemental composition of the film, induces a proportionate Sn vacancy sites such that every anion would introduce two positive type (p-type) conductor which is supported by the fact that the activation energy of the $\mathrm{SnS}$ thin film depends on elemental ratio, presence of crystal defect and the deposition method used. It is also evident from the graph that the conductance increases with temperature which indicates the semiconducting behaviour of the thin film [10].

\section{CONCLUSION}

The SnS thin film semiconductors of $0.4 \mu \mathrm{m}$ thickness were deposited using aerosol assisted chemical vapour deposition (AACV) and annealed in open air at annealing temperatures of $150,200,250,300$ and $350^{\circ} \mathrm{C}$. The annealed $\mathrm{SnS}$ thin film was found to be polycrystalline consisting of Sn and S elements in varying composition with increase in annealing temperature. No noticeable change was noticed in the crystal structure of the films while the change in the lattice parameters was marginal. No impurities peaks of elemental sulphur, tin or other tin sulphide phases were identified in the XRD pattern of the annealed films which signifies the formation of pure SnS phase. The preferred orientation of all the annealed films was found to be along the (040) plane. Increasing the annealing temperature from 150 through $250^{\circ} \mathrm{C}$ enhances the crystallinity of the annealed thin film samples by increasing the number of crystallites of the annealed films which is also buttress by the decreasing value of FWHM. However a further decrease in crystallite size at higher annealing temperature of 300 to $350^{\circ} \mathrm{C}$ was observed which could be attributed to the fragmentation of clusters of crystallites at higher annealing temperature. A decrease of dislocation density and micro strain for $\mathrm{SnS}$ thin film samples annealed at 150 to $250^{\circ} \mathrm{C}$ was noticed indicating the presence of higher crystallinity of SnS films than the samples annealed at 300 to $350{ }^{\circ} \mathrm{C}$ where the dislocation density and micro strain increases further. A gradual change was observed from the SEM micrographs in the growth of grains of SnS films from island nature to a more densely packed thin film nature as the annealing temperature increases from 150 to $350^{\circ} \mathrm{C}$. Increase in annealing temperature increases grain size leading to the reduction in grain boundaries and potential barrier thereby changing the structure and phase of the films which in essence affects the electrical conductivity of the $\mathrm{SnS}$ thin films. The films annealed at 250 ${ }^{\circ} \mathrm{C}$ showed an optimum film property for in terms of the conductivity and band gap which are essential for application as a semiconductor channel layer in a field effect transistor. The average hall coefficients of the samples deposited at 150 to $250^{\circ} \mathrm{C}$ were positive which indicates that the films annealed at this temperature range are of $p$ type (with holes as 
majority carriers) conduction while the average hall coefficients of the samples deposited at 300 and $350{ }^{\circ} \mathrm{C}$ are negative indicating that the films are of $n$ type conduction.

To the best of our knowledge and within the limit of available literature, no report has been made on the tuning of $\mathrm{SnS}$ thin film semiconductor properties with annealing in an open air environment for transistor application, hence turning the results described here innovative to the scientific community.

\section{ACKNOWLEDGEMENTS}

This research did not receive any specific grant from funding agencies in the public, commercial, or not-for-profit sectors, However, the authors acknowledged the Staff and management of Alex Ekwueme Federal University Ndufu Alike Ikwo, Ebonyi state, Federal University of Technology Minna, Sheda Science and Technology (SHESTCO), Namiroch research laboratory Abuja, iThemba Laboratory South Afica and the electron microscopy unit of the University of Western Cape, South Africa for their various contributions.

\section{Declaration of interest none.}

\section{ORCID IDs}

Dhomas Daniel, https://orcid.org/0000-0002-5176-9181; (DUno Uno, https://orcid.org/0000-0001-6693-5894

(D) Kasim Isah, https://orcid.org/0000-0002-9670-7697; (1) Umaru Ahmadu, https://orcid.org/0000-0001-5966-0853

\section{REFERENCES}

[1] T.O. Daniel, Uno EU, K.U. Isah, and U. Ahmadu, EEJP, 3, 71-80 (2019), https://doi.org/10.26565/2312-4334-2019-3-09.

[2] P. Thiruramanathan, G.S. Hikku, R. Krishna-Sharman, and S.M. Siva, International Journal of Technochem Research, 1(1), 59-65 (2015).

[3] Du H, Lin Xi, Xu Z, and Chu D, J. Mater. Sci. 50, 5641-5673 (2015), https://doi.org/10.1007/s10853-015-9121-y.

[4] H. Yuan, X. Wang, and B. Lian, National Nanotechnology, 9, 851-857 (2014), https://doi.org/10.1038/nnano.2014.183.

[5] M. Devika, N.R. Koteeswara, K. Ramesh, K.R. Gunasekhar, E.S.R. Gopal, and R.K.T. Ramakrishna, 21, 1125-1131 (2006), https://doi.org/10.1088/0268-1242/21/8/025.

[6] A. Sugaki, A. Kitakaze, and H. Kitazawa, Science Reports of the Tohoku University, Series III, 16(2), 199-211 (1985), https://www.researchgate.net/profile/Arashi_Kitakaze/publication/307507517_Synthesized_tin_and_tin-

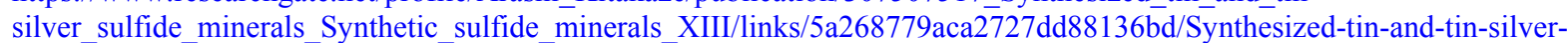
sulfide-minerals-Synthetic-sulfide-minerals-XIII.pdf.

[7] T.H. Patel, The open surface science journal, 4, 6-13 (2012), http://dx.doi.org/10.2174/1876531901204010006.

[8] B.J. Babu, A. Maldonado, S. Velumani, and R. Asomoza, Material Science and Engineering B, 174, 31-37 (2010), https://doi.org/10.1016/j.mseb.2010.03.010.

[9] M. Safonova, P.P.K. Nair, E. Mellikov, R. Aragon, K. Kerm, R. Naidu, and O. Volobujeva, Proceedings of the Estonian academy of sciences, 64(4), 488-494 (2015), http://www.kirj.ee/26577/?tpl=1061\&c_tpl=1064.

[10] E. Guneri, F. Gode, C. Ulutas, F. Kirmizigul, G. Altindemir, and C. Gumus, Chalcogenides letters, 7(12), 685-694 (2010), http://chalcogen.ro/685_Guneri.pdf.

[11] K. Nadarajah, C.Y. Chee, and C.Y. Yan, Journal of Nanomaterials, 2013, $146382 \quad$ (2013), http://dx.doi.org/10.1155/2013/146382.

[12] Rasband WS, ImageJ, National institute of health, Bethesda, Maryland, USA, http://imagej.nih.gov/ij/1997-2014.

[13] G. Julio, M.D. Merindano, M. Canals and M. Rallo, Journal of anatomy, 212, 879-886 (2008), https://doi.org/10.1111/j.14697580.2008.00898.X.

[14] T.S. Reddy and M.C. Kumar, RSC Adv. 6, 95680-95692 (2016). https://doi.org/10.1039/C6RA20129F.

\section{ТЮНІНГ ПРОВІДНОСТІ ТОНКОЮ ПЛІВКИ SnS ПРИ ВІДПАЛІ У ВІДКРИТОМУ ПОВІТРЯНОМУ СЕРЕДОВИЩІ ДЛЯ ЗАСТОСУВАННЯ В ТРАНЗИСТОРАХ \\ ${\text { Томас Даніе }{ }^{a, b}, \text { Уно Уно }^{\text {b }} \text {, Касим Iсах }{ }^{\text {b }} \text {, Умару Ахмаду }}^{b}$ \\ ${ }^{a}$ Кафедра фізики / геології / геофізики, Алекс Еквеуме, Федеральний університет Ндуфу Аліке Ікво, Р.М.В 1010, итат Ебоній, Нігерія \\ ${ }^{b}$ Кафедра фізики, Федеральний технологічний університет, Мінна P.М.В 065, Мінна, штат Нігер, Нігерія}

Дослідження спрямоване на покращення та оптимізацію провідності $\mathrm{SnS}$ за допомогою відпалу для застосування в напівпровідниковому шарі польового транзистора. Відомо, що міжвузлові атоми і вакансії в плівках $\mathrm{SnS}$ викликають пастки, які обмежують носії заряду i, отже, обмежують досягнення порогової напруги для роботи польового транзистора. Налаштування провідності $\mathrm{SnS}$ для застосування у транзисторах викликає інтерес для роботи нових пристроїв. Тонкоплівкові напівпровідники $\mathrm{SnS}$ товщиною 0,4 мкм були осаджались методом хімічного аерозольного осадження та відпалені на відкритому повітрі при температурі відпалу $150,200,250,300$ та $350^{\circ} \mathrm{C}$. Зміна температури відпалу від 150 до $250^{\circ} \mathrm{C}$ підвищує кристалічність відпалених зразків тонкої плівки за рахунок збільшення кількості кристалітів відпалених плівок, що також підкріплюється зменшенням значень FWHM. Однак спостерігалося подальше зменшення розміру кристаліту при більш високій температурі відпалу від 300 до $350^{\circ} \mathrm{C}$, що можна було пояснити фрагментацією скупчень кристалітів при більш високій температурі відпалу. Збільшення температури відпалу збільшує розмір зерна, що призводить до зменшення меж зерна та потенційного бар'єру, тим самим змінюючи структуру та фазу плівок, що по суті впливає на електропровідність тонких плівок $\mathrm{SnS}$. Плівки, відпалені при $250^{\circ} \mathrm{C}$, демонстрували оптимальну провідність. Середні коефіцієнти Холла на зразках, осаджених від 150 до $250^{\circ} \mathrm{C}$, були позитивними, що вказує на те, що плівки, відпалені в цьому діапазоні температур, мають р-тип провідності, тоді як середні коефіцієнти Холла для зразків, осаджених при $300 \mathrm{i}$ $350^{\circ} \mathrm{C}$, були негативними, що свідчить про те, що плівки мають n-тип провідності. Зміна електропровідності має важливе 
значення для використання $\mathrm{SnS}$ як шару напівпровідникового каналу, особливо в польовому транзисторі, де пристрій може бути налаштований на роботу типу напівпровідникового каналу типу р або n-типу.

КЛЮЧОВІ СЛОВА: тонка плівка $\mathrm{SnS}$, відпал, провідність, розмір зерна, транзистор, напівпровідник

\section{НАСТРОЙКА ПРОВОДИМОСТИ ТОНКОЙ ПЛЕНКИ SnS ПРИ ОТЖИГЕ В ОТКРЫТОЙ ВОЗДУШНОЙ СРЕДЕ} ДЛЯ ПРИМЕНЕНИЯ В ТРАНЗИСТОРАХ

Томас Даниэль ${ }^{\text {a,b }}$, Уно Уно $^{\mathrm{b}}$, Касим Исах ${ }^{\mathrm{b}}, \mathbf{У}_{\text {мару Ахмаду }}{ }^{\mathrm{b}}$

${ }^{a}$ Кафедра физики/геологии/геофизики, Федеральный университет Алекса Эквуэме, Ндуфу-Алике Икво, Р.М.В 1010, штат Эбони, Нигерия

${ }^{b}$ Кафедра физики, Федеральный технологический университет, Минна Р.М.В 065, Минна, итат Нигер, Нигерия

Исследование было направлено на улучшение и оптимизацию проводимости $\mathrm{SnS}$ посредством отжига для применения в полупроводниковом канале полевого транзистора. Известно, что междоузельные атомы и вакансии в пленках $\mathrm{SnS}$ вызывают ловушки носителей, которые ограничивают носители заряда и, следовательно, ограничивают достижение порогового напряжения для работы полевого транзистора. Тюнинг проводимости $\mathrm{SnS}$ для применения в транзисторах представляет интерес для работы новых устройств. Тонкопленочные полупроводники $\mathrm{SnS}$ толщиной 0,4 мкм осаждались методом аэрозольного химического осаждения из паровой фазы и отжигались на открытом воздухе при температурах отжига 150 , $200,250,300$ и $350^{\circ} \mathrm{C}$. Изменение температуры отжига от 150 до $250^{\circ} \mathrm{C}$ повышает кристалличность отожженных образцов тонких пленок за счет увеличения количества кристаллитов отожженных пленок, что также подкрепляется уменьшением значений FWHM. Однако наблюдалось дальнейшее уменьшение размера кристаллитов при более высокой температуре отжига от 300 до $350^{\circ} \mathrm{C}$, что можно объяснить фрагментацией кластеров кристаллитов при более высокой температуре отжига. Повышение температуры отжига увеличивает размер зерна, что приводит к уменьшению границ зерен и потенциального барьера, тем самым изменяя структуру и фазу пленок, что по существу влияет на электропроводность тонких пленок $\mathrm{SnS}$. Пленки, отожженные при $250^{\circ} \mathrm{C}$, показали оптимальную проводимость. Средние коэффициенты Холла образцов, нанесенных при температуре от 150 до $250^{\circ} \mathrm{C}$, были положительными, что указывает на то, что пленки, отожженные в этом диапазоне температур, имеют проводимость р-типа, в то время как средние коэффициенты Холла образцов, нанесенных при 300 и $350^{\circ} \mathrm{C}$, были отрицательными, что указывает на то, что пленки имеют проводимость n-типа. Изменение проводимости является существенным для использования $\mathrm{SnS}$ в качестве слоя полупроводникового канала, особенно в полевом транзисторе, где устройство может быть настроено для работы в качестве слоя полупроводникового канала р-типа или n-типа.

КЛЮЧОВІ СЛОВА: тонкая пленка $\mathrm{SnS}$, отжиг, проводимость, размер зерна, транзистор, полупроводник 